\title{
REVIEW
}

\section{Bluetongue virus vaccine: conventional to modern approach}

\author{
K. RANJAN ${ }^{1}$, M. PRASAD 2 , B. BRAR ${ }^{2}$, U. LAMBE 2 , R. KUMAR ${ }^{3}$, M. GHOSH ${ }^{4}$, G. PRASAD 5
}

\begin{abstract}
${ }^{1}$ Department of Veterinary Physiology and Biochemistry, Sardar Vallabhbhai Patel University of Agriculture and Technology, Meerut, Uttar Pradesh, 250110, India; ${ }^{2}$ Department of Animal Biotechnology, LLR University of Veterinary and Animal Sciences, Hisar, Haryana, 125004, India; ${ }^{3}$ Department of Veterinary Physiology, College of Veterinary \& Animal Sciences, Pookode, Wayanad 673576, India; ${ }^{4}$ APR Division, ICAR-Central Institute for Research on Buffaloes, Hisar-125 001, Haryana, India; ${ }^{5}$ Sardar Vallabhbhai Patel University of Agriculture and Technology, Meerut, Uttar Pradesh, 250110, India
\end{abstract}

\begin{abstract}
Summary. - Bluetongue (BT) is an economically important, infectious and non-contagious disease of ruminant animals. BT disease is caused by bluetongue virus (BTV) of the genus Orbivirus (the family Reoviridae). BTV is transmitted by certain species of biting midges of the genus Culicoides. Although originally $\mathrm{BT}$ was restricted to African continent, now it is present in all the continents except Antarctica. Conventional $\mathrm{BT}$ vaccines such as live attenuated and inactivated vaccines showed different degree of success in BT control. However, conventional vaccines have certain disadvantages of reversion to virulent strain and frequent booster dose requirement. Several BT outbreaks in India and the rest of the world open a new insight for development of better vaccines. The development in molecular biology techniques allowed the development and validation of several modern vaccines such as subunit vaccine, recombinant vector vaccine, disabled infections single cycle (DISC) vaccine, differentiating infected from vaccinated animals (DIVA) approach etc. Most of these vaccines are considered as safer, having better protective immune response and provided cross-protective immunization against more than one serotype.
\end{abstract}

Keywords: bluetongue virus; live vaccine; inactivated vaccine; DISC; recombinant vaccine

\section{Contents:}

1. Introduction

2. Bluetongue virus and its genome organization

3. Bluetongue virus epidemiology

4. Prophylactic immunization

5. Conventional vaccine approach

5.1 Live attenuated vaccines

5.2 Inactivated vaccine

E-mail: drkoushleshranjan@gmail.com; phone: +91-9729828914. Abbreviations: $\mathrm{BEI}=$ binary ethylenimine; $\mathrm{BT}$ = bluetongue; $\mathrm{BTV}=$ bluetongue virus; $\mathrm{CLP}(\mathrm{s})=$ core-like particle(s); DISA = disabled infectious single animal; DISC = disabled infectious single cycle; DIVA = differentiating infected from vaccinated animals; $\operatorname{LAV}(\mathrm{s})=$ live attenuated vaccine $(\mathrm{s}) ; \mathrm{MVA}=$ modified vaccinia virus Ankara; VLP(s) = virus-like particle(s); muNS-Mi = mu $(\mu)$ non-structural-microsphere
6. Modern vaccination approach

6.1 Subunit vaccines

6.2 Virus like particles (VLPs)

6.3 Plant-based BTV vaccine

6.4 DIVA (differentiation of infected and vaccinated animals) and vaccination

6.5 Recombinant viral vector vaccines

6.5.1 Herpesviruses

6.5.2 Adenovirus

6.5.3 Poxviruses

6.5.3.1 Capripox

6.5.3.2 Canary pox virus

6.5.3.3 Vaccinia virus

6.5.3.4 Modified vaccinia virus Ankara

6.6 DNA vaccines

6.7 DISC (disabled infectious single cycle) vaccines 6.8 DISA (disabled infectious single animal) vaccines 
6.9 Use of reverse genetics for vaccine development

6.10 Gene segment reassortant vaccines

7. Conclusion and future perspective

\section{Introduction}

Bluetongue (BT) disease is caused by bluetongue virus (BTV) of the family Reoviridae under the genus Orbivirus. BTV is a non-enveloped, structurally complex virus having 10 dsRNA genome segments surrounded by three concentric layers of protein shells (Verwoerd, 1969). BT is highly infectious and non-contagious, arthropod (Culicoides) vectorborne viral disease of domestic (sheep, goat and cattle) and wild (samber, deer, antilope, elk, elephant, mithun, llama etc.) ruminants (Prasad et al., 1998; Roy, 2005; Bommineni et al., 2008; Rajkhowa et al., 2008; Meyer et al., 2009). The disease is more severe in sheep, mild in case of goat, while cattle and buffalo act as reservoir (Browne, 1971). However, BT outbreaks have also been reported in cattle (Mehlhorn et al., 2008). The disease was also reported in white tailed deer (Verwoerd and Erasmus, 2004) and sporadically in South American camelids and even from carnivores (Meyer et al., 2009). BTV is transmitted by biting midges of the genus Culicoides (the family Ceratopogonidae) (DuToit, 1944). BT virus replicates in salivary glands of Culicoides (Browne and Jones, 1966). There are more than 1400 different species of Culicoides but only few are considered as competent vectors of BTV (Meiswinkel et al., 2008; Ranjan et al., 2017a,b). The BTV-infected animals are treated with symptomatic therapy, which includes gentle handling of affected animals, their stabling and administration of non-steroidal antiphlogistic drugs (Tweedle and Mellor, 2002). Other measures such as monitoring of animals through clinical, serological and virological examinations as well as monitoring of insect vectors are also adapted. The prophylactic immunisation with suitable antiviral preparations and removal or prevention of vectors attack to animals can be ensured.

\section{Bluetongue virus and its genome organization}

The virion particle of BTV is icosahedral and nonenveloped. It consists of inner core and outer capsid. The whole genome of BTV is of $19 \mathrm{kbp}$ and consists of ten dsRNA segments and encodes 7 structural (VP1 to VP7) and 5 nonstructural (NS1, NS2, NS3/NS3A, NS4 and NS5) proteins (Mertens et al., 1984; Belhouchet et al., 2011; Stewart et al., 2015). Segment 1-encoded VP1 protein forms transcription complex along with VP4 and VP6 proteins and acts as RNAdependent RNA polymerase (Roy et al., 1988). Segment 2-encoded VP2 protein forms triskelion motifs on outer capsid of virion particle. VP2 protein is responsible for he- magglutination, receptor binding and serotype specificity of the virus (Hassan and Roy, 1999). VP5 protein is arranged as trimers that form outer-layer globular motifs of BTV particle (Nason et al., 2004). VP5 protein is significantly conserved and acts as minor serotype-specific protein (Singh et al., 2005). VP5 protein also assists in release of mature virion particle from the endosomal compartment to the cytoplasm of the host cell (Hassan et al., 2001).

Segment 3-encoded VP3 protein is highly conserved and forms inner most sub-core icosahedral symmetry of the virion particle (Loudon and Roy, 1992). Segment 4-encoded VP4 protein is guanylyl-transferase or transmethylase and acts as capping enzyme. Similarly, VP6 protein shows helicase and NTPase activity and binds with ssRNA and dsRNA. The VP7 is a serogroup-specific protein found on outer core surface of virion particle. The non-structural proteins are expressed in infected host cells and are not part of the virion particle. The NS1 protein forms tubules for translocation of progeny virus particles to the cell membrane in infected host cell (Owens et al., 2004). The ssRNA-binding NS2 protein forms inclusion body in host cell cytoplasm (Owens et al., 2004). NS3 and NS3a are expressed in insect cells only and assist in release of virion particles from infected cells (Hyatt et al., 1993). Recently, two more NS proteins NS4 and NS5 have also been reported, whose actual functions are yet to be confirmed.

\section{Bluetongue virus epidemiology}

BT infection is stretched from $35^{\circ} \mathrm{S}$ to $40^{\circ}-50^{\circ} \mathrm{N}$ of the globe. The restriction in geographical distribution of BTV can be corelated with favorable environmental and climatic conditions, which support the Culicoides breeding. Culicoides vectors can transmit BTV to long distances in new geographical areas (Burgin et al., 2012). There are 27 distinct BTV serotypes have been identified worldwide so far (Hofmann et al., 2008; Jenckel et al., 2015). All these serotypes are determined based on specific interaction of viral outermost VP2 protein of a particular serotype with corresponding neutralizing antibodies in serum neutralization assays (Eaton et al., 1990; Maan et al., 2007).

India is endemic for BTV because the tropical rainy climate of country favors the breeding of Culicoides vector. It was estimated that India harbors 63 distinct Culicoides species in different geographical locations (Ranjan et al., 2015). However, only a few species of Culicoides have been demonstrated as potent vector for BTV transmission. Recently, Culicoides oxystoma and Culicoides peregrinus were reported as potent vector of BTV 16 and 23 in India (Ranjan et al., 2017a,b). Out of 27, a total of 24 different BTV serotypes (except BTV serotypes 25, 26 and 27) have been reported from different regions of India (Prasad et al., 2009; 
Minakshi et al., 2012; Dadawala et al., 2013; Kumar et al., 2013; Prasad et al., 2013; Ranjan et al., 2013, 2014a,b, 2015; Vishwaradhya et al., 2013; Maan et al., 2015; Krishnajyothi et al., 2016; Hemadri et al., 2017; Reddy et al., 2017).

Similarly, 12 BTV serotypes (BTV1, 2, 3, 5, 7, 9, 12, 15, 16, 20,21 and 23) have been isolated in Australia (Melville et al., 2015). BT virus is mostly endemic in northern Australia and its distribution extends down the east coast into New South Wales and south of Sydney, where climate is favorable for Culicoides vector. However, clinical form of BT disease is not much reported in Australia, possibly due to limited overlap between sheep farming regions and those places, where BTV is prevalent (Firth et al., 2017). China is also endemic for several BTV serotypes but predominant are BTV1, 2,3,4,12,15 and 16 (Zhang et al., 2010). BT has also showed considerable socioeconomic concern in European Union nations. Once it was considered an exotic disease in Europe. Now it is well established that at least 6 BTV serotypes (BTV1, 2, 4, 8, 9 and 16) were continuously present in Europe. Later on, BTV8 has caused a severe epizootic outbreak in northern Europe (Saegerman et al., 2008).

Sequence data analysis showed that viruses of western lineages circulate in Africa, Caribbean and the Americas. However, eastern lineages of BTV are found endemic in Australia, Asia and Indonesia (Carpi et al., 2010). The segmented nature of BTV genome allowed the reassortment of its genome, which results in BT virus with genome segments from different parent BT viruses (He et al., 2010). Surveys have indicated that South Africa is endemic for BTV and 22 of the known 26 serotypes are present with serotypes 20,21, 25 and 26 being considered as exotic (Coetzee et al., 2012). Cattle, indigenous sheep breeds and wild ruminants are frequently infected by multiple serotypes but rarely demonstrate clinical signs of BT disease. However, European sheep breeds usually showed clinical form of disease (Coetzee et al., 2012). USA is also endemic for BTV. Several studies have reported the prevalence of BTV serotypes $1,2,3,4,6,8,10,11,12,13$, $14,17,19$ and 22 in USA (Schirtzinger et al., 2018).

\section{Prophylactic immunization}

The prophylactic vaccination may prevent the clinical manifestation of BT in animals. Vaccination results in interruption of BTV cycle and ensures that lesser number of animals would be infected by BTV. Thus, it reduces the economic loss caused by BT by safer transfer and trading of animals from BTV enzootic regions to other countries (Savini et al., 2008; Bhanuprakash et al., 2009; Caporale and Giovannini, 2010). BTV serotypes usually show very poor cross-protective immunity. Moreover, BTV serotypes are not uniformly distributed in a geographical region. Therefore, during selection and formulation of BTV vaccine, serotype specificity and local area BTV prevalence should be taken into account (Bhanuprakash et al., 2009). In a region with a history of single serotype BT outbreaks, vaccination against that serotype is needed for protection against viremia. In contrary, in a region with multiple serotype prevalence, protection against all the circulating serotypes is required. However, the ideal single BT vaccine for all regions is not available (Feenstra et al., 2017). For BT control, several types of vaccination approach such as live attenuated, inactivated, subunit and many modern vaccine formulations have been in use. Each of the vaccination approaches has its own advantages and disadvantages (Table 1).

\section{Conventional vaccine approach}

\subsection{Live attenuated vaccines}

Live attenuated vaccines (LAV) are prepared from living pathogens that have been weakened in laboratory. They are derived from wild type disease-causing microorganisms. LAVs lead to an excellent immune response because they provide continuous antigenic stimulation for memory cell production. In the case of viruses or other intracellular microorganisms, where mostly cell-mediated immunity is desired, LAV may be a choice because they are capable of replicating within host cells. For BT control, LAV is only the commercially available vaccine in endemic regions, where multiple serotypes of virus are prevalent (Caporale and Giovannini, 2010). In BT endemic regions such as South Africa, multivalent live attenuated vaccines against several BTV serotypes are still in use (Veronesi et al., 2005). A single dose of LAV also elicits sufficient immune response and protective immunity against virulent strain of European BTV serotype 8 in sheep. Post vaccination, vaccinated animals didn't show any clinical signs, while the unvaccinated sheep showed severe clinical signs of BT (Dungu et al., 2008).

LAVs are generally produced by either serial passages in cell lines followed by lyophilisation (freeze drying) process. The serial passages of BTV4, 9 and 16 in BHK-21 or Vero cell cultures reduced the viral replication capability in bovine fetal aorta (BFA) cell line as compared to virulent homologous strains (Franchi et al., 2008). The vaccines produced from attenuated BTV9 or BTV4 strains were found safe, immunogenic and elicit sufficient immune response to prevent viremia and clinical disease symptoms in sheep following challenge with virulent homologous BTV strains (Franchi et al., 2008). A freeze dried polyvalent Onderstepoort LAV for BT (Reg. No. G 358 Act No. 36/1947) was validated for prophylactic immunisation in sheep (OBP, 2013). The polyvalent LAV comprises of 3 bottles having several BTV serotypes such as Bottle A (BTV serotypes 1, 4, 6, 12 and 14), Bottle B (BTV serotypes 3, 8, 9, 10 and 11) and Bottle 
Table 1. Comparison of different strategies of bluetongue vaccines

\begin{tabular}{|c|c|c|c|c|}
\hline S.n. & Vaccine & Vaccine formulation & Advantages & Disadvantages \\
\hline 1 & $\begin{array}{l}\text { Modified live vaccines } \\
(\mathrm{MLVs})\end{array}$ & $\begin{array}{l}\text { Live BT virus allowed for several passages in } \\
\text { cell culture or host system. Post vaccination, } \\
\text { viruses replicate in host animal without caus- } \\
\text { ing disease and elicit immunity against BTV. }\end{array}$ & $\begin{array}{l}\text { Usually single dose vaccina- } \\
\text { tion is possible. } \\
\text { Cost effective. } \\
\text { Immunity can persist for } \\
\text { several years. }\end{array}$ & $\begin{array}{l}\text { Possibility of revertion back to virulent } \\
\text { strain due to genetic reassortment with } \\
\text { virulent BTV strains. } \\
\text { Possibility of transmission by Culi- } \\
\text { coides vector. } \\
\text { Several side effects such as abortion, } \\
\text { decreased milk yield etc. reported. }\end{array}$ \\
\hline 2 & $\begin{array}{l}\text { Killed or inactivated } \\
\text { vaccines }\end{array}$ & $\begin{array}{l}\text { BT virus are inactivated by UV radiation, heat } \\
\text { treatment and chemical agents and mixed with } \\
\text { specific adjuvant, which stimulates the im- } \\
\text { mune system against the antigens available on } \\
\text { inactivated viruses. }\end{array}$ & $\begin{array}{l}\text { Cannot reassort with viru- } \\
\text { lent BTV strains. } \\
\text { Considered as safe vaccine. }\end{array}$ & $\begin{array}{l}\text { Multivaccine doses are required as im- } \\
\text { munity exists for short time. } \\
\text { Hypersensitivity to adjuvant in host is } \\
\text { possible. }\end{array}$ \\
\hline 3 & $\begin{array}{l}\text { Recombinant vector } \\
\text { vaccines }\end{array}$ & $\begin{array}{l}\text { BTV-specific antigenic genes are introduced in } \\
\text { genetically modified non-pathogenic viruses } \\
\text { to elicit immunity against BTV. Such modified } \\
\text { viruses are used for vaccination to animals. }\end{array}$ & $\begin{array}{l}\text { Usually single dose vaccina- } \\
\text { tion is used. } \\
\text { Strong neutralizing immu- } \\
\text { nity is observed. }\end{array}$ & $\begin{array}{l}\text { Technically difficult to design. } \\
\text { Expensive in nature. }\end{array}$ \\
\hline 4 & $\begin{array}{l}\text { Disabled infectious } \\
\text { single cycle (DISC) } \\
\text { vaccines }\end{array}$ & $\begin{array}{l}\text { Deletion of an essential gene results in modi- } \\
\text { fied BTV virions, which will replicate one time } \\
\text { post vaccination. Purified single cycle BTV } \\
\text { viruses are used as vaccine. }\end{array}$ & $\begin{array}{l}\text { Risk of reversion to viru- } \\
\text { lence is lower. }\end{array}$ & $\begin{array}{l}\text { Difficult to design the vaccine. } \\
\text { Expensive in nature. } \\
\text { Multiple doses are required. }\end{array}$ \\
\hline 5 & $\begin{array}{l}\text { Disabled infectious } \\
\text { single animal (DISA) } \\
\text { vaccine }\end{array}$ & $\begin{array}{l}\text { BT virus without expressing non-structural } \\
\text { proteins NS3/NS3a is used as DISA vaccine. } \\
\text { It is a replicating vaccine, induces serotype- } \\
\text { specific protection without causing detectable } \\
\text { viremia. }\end{array}$ & $\begin{array}{l}\text { Risk of reversion to viru- } \\
\text { lence is lower. } \\
\text { Chimeric vaccine against } \\
\text { more than serotype is pos- } \\
\text { sible. }\end{array}$ & $\begin{array}{l}\text { Difficult to design the vaccine. } \\
\text { Expensive in nature. }\end{array}$ \\
\hline 6 & $\begin{array}{l}\text { Differentiating infect- } \\
\text { ed from vaccinated } \\
\text { animals (DIVA) }\end{array}$ & $\begin{array}{l}\text { In DIVA strategy vaccine is based on a dif- } \\
\text { ferent strain than the current field strain. A } \\
\text { serological test is used to differentiate between } \\
\text { vaccine-induced antibodies and antibodies } \\
\text { against the field virus. }\end{array}$ & $\begin{array}{l}\text { Can differentiate between } \\
\text { infected and vaccinated } \\
\text { animals. } \\
\text { Special restrictions, neces- } \\
\text { sary for infected animal's } \\
\text { trade, can be avoided for } \\
\text { vaccinated animals. } \\
\end{array}$ & $\begin{array}{l}\text { DIVA vaccine is not so effective in } \\
\text { comparison to conventional vaccines. } \\
\text { Special DIVA tests have to be devel- } \\
\text { oped, which are sometimes not as } \\
\text { sensitive as conventional tests. }\end{array}$ \\
\hline 7 & $\begin{array}{l}\text { Virus-like particle } \\
\text { vaccines }\end{array}$ & $\begin{array}{l}\text { Insect cell-grown genetically modified baculo- } \\
\text { virus vectors express BTV structural proteins, } \\
\text { which assemble into empty viral particles. } \\
\text { Such purified viral particles with adjuvants are } \\
\text { used as vaccine. }\end{array}$ & $\begin{array}{l}\text { Lower possibility of side } \\
\text { effects. } \\
\text { High stability. } \\
\text { No risk of disease. }\end{array}$ & $\begin{array}{l}\text { Multiple doses required. } \\
\text { Difficult to design the vaccine. } \\
\text { Expensive in nature. } \\
\text { Local reaction to adjuvant possible. }\end{array}$ \\
\hline
\end{tabular}

C (BTV serotypes 2, 5, 7, 13 and 19) (Table 2) (OBP, 2013). The lyophilized strains of BTV4 and 16 used as live vaccine elicit sufficient protective immune response in sheep, which was evidenced by absence of illness in animals following challenge with virulent homologous strain (Table 2) (Zhugunissov et al., 2015).

Although the production cost of LAVs is lower (Savini et al., 2008; Bhanuprakash et al., 2009), they may lose efficiency in tropical conditions, especially if the temperature is above $35^{\circ} \mathrm{C}$ (Hammoumi et al., 2003). Certain concerns regarding safety of LAVs have also been raised. LAVs generally produce viremia, which lasts over two weeks in vaccinated sheep (Veronesi et al., 2005). It may provide an opportunity for vectors to spread live vaccine virus to other healthy animals. Thus, within vector or host, live vaccine virus may either revert to virulent virus or produce a recombinant progeny virus after reassortment of genes between LAV virus and wild type BTV strains (Tweedle and Mellor, 2002; Veronesi et al., 2005; Savini et al., 2008). Some of the Indian BT viruses such BTV2 (isolate IND2003/02) and BTV10 (isolate IND2004/01) showed $>99 \%$ nucleotide identity with live attenuated vaccine strains of BTV2 from South Africa (Maan et al., 2015) and BTV10 from USA (Maan et al., 2012), respectively, which indicates their possible origin from LAV (Ranjan et al., 2015). It is also observed that multivalent LAVs elicit poor immune response. Moreover, LAVs may lead to appearance of clinical signs of BT such as reduced milk production, abortion, stillbirth, poor semen quality in rams (Breard et al., 2007; Savini et al., 2008) and fetal malformation in ewes (Tweedle and Mellor, 2002; Bhanuprakash et al., 2009). The study by some of the researchers showed that BTV2 and BTV9 LAV strains can cross the placental barrier of cattle, sheep and goats and 
Table 2. Live attenuated vaccines used for bluetongue disease

\begin{tabular}{|c|c|c|c|c|}
\hline Virus origin & BTV serotype & Strain & Remarks & Reference \\
\hline RSA, 1958 & BTV1 & Biggarsberg/8012 & \multirow{16}{*}{$\begin{array}{l}\text { For use in sheep } \\
\text { only }\end{array}$} & \multirow{16}{*}{ (European Commission, 2000; OBP, 2013) } \\
\hline RSA, 1958 & BTV2 & Vryheid/5036 & & \\
\hline Cyprus, 1944 & BTV3 & Cyprus/8231 & & \\
\hline $\mathrm{RSA}, \sim 1900$ & BTV4 & Theiler/79043 & & \\
\hline RSA, 1953 & BTV5 & Mossop/4868 & & \\
\hline RSA, 1958 & BTV6 & Strathene/5011 & & \\
\hline RSA, 1955 & BTV7 & Utrecht/1504 & & \\
\hline RSA, 1937 & BTV8 & Camp/8438 & & \\
\hline RSA, 1942 & BTV9 & University Farm/2766 & & \\
\hline Portugal, 1956 & BTV10 & Portugal/2627 & & \\
\hline RSA, 1944 & BTV11 & Nelspoort/4575 & & \\
\hline RSA,1941 & BTV12 & Estantia/75005 & & \\
\hline RSA, 1959 & BTV13 & Westlands/7238 & & \\
\hline RSA, 1959 & BTV14 & Kolwani/89/59 & & \\
\hline RSA, 1976 & BTV19 & $143 / 76$ & & \\
\hline Pakistan & BTV16 & Pakistan/7766 & & \\
\hline China & $\begin{array}{l}\text { BTV1 } \\
\text { BTV16 }\end{array}$ & Live attenuated & $\begin{array}{l}\text { For use in sheep } \\
\text { and goat }\end{array}$ & Zhang et al., 2004 \\
\hline RSA & $\begin{array}{l}\text { BTV2 } \\
\text { BTV8 }\end{array}$ & Modified live vaccines & For use in sheep & Modumo and Venter, 2012 \\
\hline $\begin{array}{l}\text { Republic of } \\
\text { Kazakhstan }\end{array}$ & $\begin{array}{l}\text { BTV4 } \\
\text { BTV16 }\end{array}$ & $\begin{array}{l}\text { Khuroson-40/13/4 RT/ } \\
\text { RIBSP40/13/16 }\end{array}$ & For use in sheep & Zhugunissov et al., 2015 \\
\hline USA & BTV10 & Modified live virus of BTV 10 & $\begin{array}{l}\text { For use in sheep } \\
\text { and goat }\end{array}$ & http://www.colorado-serum.com/pdf/csc_catalog.pdf \\
\hline Turkey & BTV4 & $\begin{array}{l}\text { SA BT/4, Freeze Dried, } \\
\text { Monovalent, live attenuated }\end{array}$ & For use in sheep & $\begin{array}{l}\text { http://www.cfsph.iastate.edu/ } \\
\text { Vaccines/manufacturer_list. } \\
\text { php?manufacturer=126\&lang=en }\end{array}$ \\
\hline USA & $\begin{array}{l}\text { BTV10 } \\
\text { BTV11 } \\
\text { BTV17 }\end{array}$ & $\begin{array}{l}\text { Bluevac-10 } \\
\text { Bluevac-11 } \\
\text { Bluevac-17 }\end{array}$ & For use in sheep & $\begin{array}{l}\text { California Wool Growers Association http:// } \\
\text { cawoolgrowers.org/vaccines/ } \\
\text { bluetongue.html }\end{array}$ \\
\hline
\end{tabular}

RSA: Republic of South Africa; BTV: Bluetongue virus.

are able to infect fetuses leading to malformations or abortions depending on term of pregnancy (Savini et al., 2014). Due to abortion and fetal malformation, LAVs in ewes are recommended nine to 15 weeks before mating and in rams after the mating period (Bhanuprakash et al., 2009).

However, some of the previous reports claim that is difficult to prove the assumption that either LAVs may revert back to virulent strain or reassorted with field BTV strain which give rise to a new virus strain (European Commission, 2000). Due to difficulty in experiment and unfeasible nature of result, no virus transmission trials have been conducted between vaccinated sheep-vector-unvaccinated ruminants. It was reported that attenuated viruses that elicit titers of less than 1000 plaque forming units (PFU) per ml of blood at height of viremia in animals will not be transmitted by bloodsucking Culicoides vector (OIE, 1996). Thus most of the commercially produced LAVs may be treated as safe because they elicit viremia lower than $1000 \mathrm{PFU} / \mathrm{ml}$ of blood (European Commission, 2000).

\subsection{Inactivated vaccine}

The inactivated vaccines mostly produce humoral immune response. Inactivated vaccines have some added advantages over LAVs such as inactivated virus eliminates concerns about reversion to virulent strain, reassortment with field strains and viremia and vector transmission. Moreover, it also positively addresses the problems of abortion and danger of fetal infection, which often arise from live attenuated BT vaccines. The inactivated vaccines can also be utilised for rapid response against new emerging serotypes. The new serotypes are molecular characterized by cloning and sequencing techniques, which is a time-taking process. Thus, vaccine development after complete molecular characterization of pathogen may lead to severe economic losses. However, inactivated BT vaccines can be prepared within short time by inactivation of BTV using suitable agents such as gamma radiation (Campbell, 1985), $\beta$-propialactone (Savini et al, 2007) and binary ethylenimine (Ramakrishnan 
Table 3. Inactivated vaccines used for bluetongue disease

\begin{tabular}{|c|c|c|c|}
\hline Country & BTV serotype & Vaccine characteristics & Reference \\
\hline \multirow[t]{5}{*}{ India } & BTV18 & $\begin{array}{l}\text { Hydroxylamine inactivated and adjuvanted with } \\
\text { aluminium hydroxide }(\mathrm{Al}[\mathrm{OH}](3)) \text { gel, saponin, or } \\
\mathrm{Al}(\mathrm{OH})(3) \text { gel/saponin. }\end{array}$ & Ramakrishnan et al., 2005 \\
\hline & BTV1 & $\begin{array}{l}\text { Inactivated with binary ethyleneimine and adjuvanted } \\
\text { with saponin. }\end{array}$ & Pandey et al., 2006 \\
\hline & BTV1 & $\begin{array}{l}\text { Binary ethylenimine (BEI) inactivated vaccine showed } \\
\text { cross protective immune response against heterologous } \\
\text { BTV23 serotype challenge in Indian native sheep. }\end{array}$ & Umeshappa et al., 2010 \\
\hline & BTV2, 9, 15 & $\begin{array}{l}\text { Inactivated vaccine against BTV2, } 9 \text { and 15, under } \\
\text { development. }\end{array}$ & Balam et al., 2011 \\
\hline & Pentavalent (BTV1, 2,10, 16, 23) & $\begin{array}{l}\text { Inactivated pentavalent BTV vaccine consisting } \\
\text { of BTV1, 2, 10, } 16 \text { and } 23 \text { with Montanide ISA50 } \\
\text { adjuvant. }\end{array}$ & Reddy et al., 2010 \\
\hline China & BTV1, 16 & Inactivated BTV vaccine. & Zhang et al., 2004 \\
\hline \multirow[t]{2}{*}{ USA } & BTV11,17 & BEI-inactivated and $\mathrm{Al}(\mathrm{OH}) 3$ adjuvanted. & Berry et al., 1982 \\
\hline & BTV11,17 & Inactivated vaccine. & Stevens et al., 1985 \\
\hline \multirow[t]{11}{*}{ European Union } & BTV8 (BTVPUR AlSap $8^{\circledast}$ ) & \multirow{11}{*}{$\begin{array}{l}\text { Purified virus inactivated in } \mathrm{Al}(\mathrm{OH}) 3 \text { and saponin } \\
\text { adjuvants supplemented. }\end{array}$} & \multirow{11}{*}{$\begin{array}{l}\text { Center for Food Security and } \\
\text { Public Health, Iowa State } \\
\text { University } \\
\text { http://www.cfsph.iastate.edu/ } \\
\text { Vaccines/disease_list.php? } \\
\text { disease=bluetongue\&lang=en }\end{array}$} \\
\hline & BTV8 (BOVILIS ${ }^{\oplus}$ BTV8) & & \\
\hline & BTV1 (BTVPUR AlSap $\left.{ }^{\text {ta }} 1\right)$ & & \\
\hline & BTV 1 and 8 (BTVPUR AlSap $\left.{ }^{\text {Tw }} 1-8\right)$ & & \\
\hline & BTV 2 and 4 (BTVPUR AlSap ${ }^{\text {tm }} 2-4$ ) & & \\
\hline & BTV8 (Zulvac 8 Bovis) & & \\
\hline & BTV8 (Zulvac 8 Ovis) & & \\
\hline & BTV1 (Zulvac 1 Bovis) & & \\
\hline & BTV1 (Zulvac 1 Ovis) & & \\
\hline & BTV1 and 8 (Zulvac $1+8$ Bovis) & & \\
\hline & BTV1 and 8 (Zulvac $1+8$ Ovis) & & \\
\hline France, Spain & BTV1 (BLUEVAC $\left.{ }^{\circledast} 1\right)$ & Adjuvanted with Aluminum hydroxide and saponin. & \\
\hline \multirow[t]{4}{*}{ Spain } & BTV4 (BLUEVAC $\left.{ }^{\oplus} 4\right)$ & Adjuvanted with oil. & \\
\hline & BTV8 (BLUEVAC $\left.{ }^{\circledast} 8\right)$ & Mixed with aqueous adjuvant. & \\
\hline & BTV1 and $4\left(\right.$ BLUEVAC $\left.^{\circledast} 1+4\right)$ & Mixed with aqueous adjuvant. & \\
\hline & BTV1 and $8\left(\right.$ BLUEVAC $\left.^{\oplus} 1+8\right)$ & Mixed with aqueous adjuvant. & \\
\hline Several countries & BTV8 (BIOBOS BTV 8) & Adjuvanted with oil. & \\
\hline \multirow[t]{3}{*}{ Italy } & BTV2 & $\begin{array}{l}\text { Beta-propiolactone inactivated and adjuvanted with } \\
\text { ISA } 206 .\end{array}$ & Emidio et al., 2004 \\
\hline & BTV2, 4 & $\begin{array}{l}\text { Bivalent inactivated bluetongue vaccine and } \\
\text { adjuvanted with ISA } 206 .\end{array}$ & Savini et al., 2009 \\
\hline & BTV16 & $\begin{array}{l}\text { Beta-propiolactone inactivated and adjuvanted with } \\
\text { ISA } 206 .\end{array}$ & Savini et al., 2007 \\
\hline \multirow{4}{*}{$\begin{array}{l}\text { Mexico, } \\
\text { Portugal, Spain }\end{array}$} & BTV1 (Syvazul 1) & & \multirow{4}{*}{$\begin{array}{l}\text { Center for Food Security and Pub- } \\
\text { lic Health, Iowa State University } \\
\text { http://www.cfsph.iastate.edu/ } \\
\text { Vaccines/disease_list.php? } \\
\text { disease=bluetongue\&lang=en }\end{array}$} \\
\hline & BTV4 (Syvazul 4) & & \\
\hline & BTV8 (Syvazul 8) & Adjuvanted with oil. & \\
\hline & BTV1 and 8 (Syvazul 1+8) & & \\
\hline
\end{tabular}

BEI: Binary ethylenimine; BTV: Bluetongue virus; ISA: Incomplete seppic adjuvant.

et al., 2006) (Table 3). These vaccines are administered along with suitable adjuvants. Some of the inactivated commercial BT vaccines have shown good safety and immunogenicity potency (Savini et al., 2008). The monovalent inactivated vaccines against BTV2 and BTV4 and also bivalent vaccines against BTV2 and 4 were prepared in Southern Europe (Sa- vini et al., 2009). However, now monovalent vaccines against BTV1, 8 and 9 are also available (Zientara et al., 2010). The vaccination using commercial inactivated vaccine against BTV serotype 8 (BTVPUR AlSap 8) with recommended schedule can effectively protect from wild type virus (Spedicato et al., 2017). It was reported that first vaccination with 
this vaccine (BTVPUR AlSap 8), two weeks prior to challenge was able to prevent viremia (Spedicato et al., 2017). Thus, it can prevent an unexpected BTV 8 outbreak in sheep, which has significant impact on management and legislation on sheep trade from BTV endemic areas.

The inactivated vaccines also have added advantage of DIVA strategies, which can easily differentiate between infected and vaccinated animals (Bhanuprakash et al., 2009). However, it is difficult to predict the protective immune response of inactivated vaccine against heterologous serotypes. Although, protection against heterologous serotype may occur, it is difficult to say whether the protection is partial or complete (Breard et al., 2015). Moreover, the production costs of inactivated vaccines are higher in comparison to attenuated vaccines. They elicit immunity for a short time and also require few booster doses with an adjuvant to generate a protective immune response.

\section{Modern vaccination approach}

Most of the currently used BT vaccines are either live attenuated or inactivated virus vaccines. Although such approach is useful in many instances, it has certain limitations. The multiple serotypes and evolution of reassortant viruses due to exchange of genome segments lead to major problems in control of BT. Thus, new generation vaccines are required for proper BT control. Several approaches have been made for development of new generation vaccines against BTV such as subunit vaccines, recombinant vector vaccines, virus-like particles (VLP) etc. They offer added advantages over traditional vaccines such as rapid onset of immune response, no risk of virus transmission, options to make them polyvalent and DIVA vaccines approach (Savini et al., 2008; Bhanuprakash et al., 2009; Roy et al., 2009). However, they possess some of the major disadvantages such as technical expertise in production, which leads to higher cost of the vaccine (Bhanuprakash et al., 2009).

\subsection{Subunit vaccines}

Subunit vaccines contain only the antigenic parts of the pathogen, which are necessary to elicit a protective immune response in host. The high precision of subunit vaccines comes at a cost, because various subunits of pathogen are examined in detail to determine particular combinations, which will elicit effective immune response (WHO, 2013). Although purified VP2 protein elicits sufficient protective immune response in sheep, this strategy could not be progressed further to prepare subunit vaccine due to requirement of large amount of VP2 protein for each individual virus serotype. The purified VP2 protein can be used for vaccine development against specific BTV serotypes only
(Huismans et al., 1987). Later on, subunit vaccine was prepared using expression of BTV proteins in recombinant baculovirus systems (Roy, 1990). The individual BTV10 proteins purified from baculovirus vectors were administered in sheep in different combinations and doses and challenged with homologous virus (Roy et al., 1990). A combination of $50 \mu \mathrm{g}$ of VP2 and $20 \mu \mathrm{g}$ of VP5 elicit sufficient protective immune response against homologous virus. However, alone of VP2 protein $100 \mu \mathrm{g}$ was required to elicit protective immune response. This indicates the protective role of VP5 protein in generation of immune response along with VP2 protein. However, the addition of other BTV-specific proteins such as VP3, VP7, VP1, VP6, NS1, NS2 and NS3 to VP2/VP5 did not show any increase in protective immune response (Roy et al., 1990).

The recombinant VP2 protein of BTV8 along with NS1 and NS2 of BTV2 mixed with immune stimulating complex (ISCOM) adjuvant was used as subunit vaccine against BTV8 in cattle calves (Anderson et al., 2014). BTV antigenic proteins were also expressed in bacterial and yeast expression systems to produce recombinant BTV proteins (Gould et al., 1994; Pathak et al., 2008). The VP2, VP5 and VP7 proteins of BTV8 were also expressed in bacteria. The VP2 protein was expressed as either three separate overlapping fragments or a single full length complete protein, whereas VP5 and VP7 were expressed as full length proteins. These proteins were tested as subunit vaccine in IFNAR (-/-) mice (Jabbar et al., 2013). The fragmented VP2 protein along with VP5 and VP7 in adjuvant Montanide ISA-50V preparation did not show any neutralizing antibodies against BTV8. In addition, complete VP2 protein along with VP5 and VP7 in adjuvant Montanide ISA-50V preparation showed only partial protection against BTV8 (Jabbar et al., 2013). An experimental subunit vaccine against BTV4 was also formulated and tested in guinea pigs and cattle (Legisa et al., 2015). The VP2 protein of BTV4 from Argentina was expressed in baculovirus insect cell expression system either alone or fused with antigen-presenting cell homing (APCH) molecules (Legisa et al., 2015). The VP2 or APCH-VP2 vaccinated guinea pigs and cattle elicited high neutralizing antibody titers similar to conventional inactivated vaccines. However, IFNAR(-/-) mouse model immunized with APCH-VP2 showed enhanced cellular immune response and neutralizing activity compared to that induced by VP2 alone (Legisa et al., 2015). A new approach of subunit vaccine preparation was also developed using incorporation of VP2, VP7 and NS1 protein of BTV4 into avian reovirus (ARV), muNS-Mi (mu ( $\mu$ ) nonstructural-microsphere) microspheres (MS-VP2/MS-VP7/ MS-NS1) (Marín-López et al., 2014). The IFNAR(-/-) mice vaccinated with muNS-Mi microspheres showed complete protection against challenge with homologous BTV4 and a partial protection against heterologous BTV1 serotype. The microspheres-based subunit vaccine has additional ad- 
vantage of potent intrinsic adjuvant activity and stimulates specific T cell responses (CD4+) against the virus (MarínLópez et al., 2014).

\subsection{Virus-like particles (VLPs)}

VLPs have been successfully utilised against BTV for subunit vaccine formulation. Although VLPs are non-infectious particles, they resemble viruses and elicit protective immune response because they express viral structural proteins such as capsid or envelope. The vp2 and vp5 genes of BTV10 were inserted into a recombinant baculovirus along with baculovirus polyhedrin promoter (French et al., 1990). The insect cells ( $S$. frugiperda) co-infected with this recombinant virus along with another recombinant baculovirus expressing major core proteins VP3 and VP7 of BTV17 and BTV10, respectively, (French and Roy, 1990) yielded double-shelled, non-infectious VLPs. These VLPs were found very similar in size and appearance to BTV virion particles. Moreover, antibodies raised against these VLPs showed significantly higher neutralizing activity against homologous BTV serotype (French et al., 1990). VLPs are considered as safe and have shown effective immune response against BTV (Roy and Noad, 2008; Barr and Tamms, 2007). VLPs are the only vaccines allowed for intensive clinical trials in different countries. Two doses of VLPs are sufficient for long-lasting protection. The production costs of VLPs are also reasonable due to technical advancement in insect cell culture manufacturing.

The first approach of VLP vaccination against BTV10 was performed when co-expression of four major structural proteins (VP2, VP5, VP3 and VP7) was used to assemble the VLP (Roy, 1990). Later on VLPs against several BTV serotypes such as BTV1, 2, 10, 13 and 17 in combination were prepared, which elicit sufficient protective immune response against homologous serotype in sheep (Roy et al., 1994). VLPs against BTV8 in combination with BTV1 and 2 were validated, which also showed protective immunity against homologous BTV serotypes (Stewart et al., 2013). VLPs in combination with adjuvant may elicit sufficient immune response at lower dose of VLP antigen. It was reported that only $10 \mu \mathrm{g}$ of BTV VLPs in combination with adjuvant such as Freunds' adjuvant or an incomplete Montanide ISA-50 elicit sufficient immune response when challenged with homologous serotype (Roy et al., 1992). Moreover, the baculovirus expression system was used for co-expression of VP3 and VP7 proteins, which assembled as core-like particles (CLPs). However, these CLPs did not elicit complete immune response against BTV (Stewart et al., 2012; Thuenemann et al., 2013). It suggests that VP2 and VP5 are essential components of a subunit vaccine against BTV.

\subsection{Plant-based BTV vaccine}

The plants can be used as molecular farming to produce desirable recombinant proteins, which can be used as vaccine products. Initially, plant based-vaccine was developed with the idea that these plant products can be directly used as edible vaccine. However, this concept is now obsolete because vaccine products require some kind of purification, standardisation of dose, quality control and formulation in suitable delivery form (Rybicki, 2009, 2014). Plants have a potential for production of heteromultimeric protein complexes because plant expression systems can simultaneously express multiple desirable genes. This strategy can be used for production of BTV-like particles (VLPs) using desirable genes. The antigenic proteins VP2 and VP5 and major core proteins VP3 and VP7 of BTV8 were assembled using cowpea mosaic virus-based HyperTrans (CPMV-HT) and pEAQ plant expression vector system (Thuenemann et al., 2013). The recombinant cowpea mosaic viruses were allowed to propagate in Nicotiana benthamiana plant. The purified virion particles elicited a strong antibody response in sheep and provided protective immunity against a South African BTV8 challenge infection. It was also found safe and without any clinical manifestation in sheep (Thuenemann et al., 2013). In another approach, bluetongue VLPs and core likeparticle (CLP) were expressed in N. benthamiana plant by infection with Agrobacterium tumefaciens using recombinant pEAQ-HT plasmid separately encoding four BTV8-specific (VP2, VP3, VP5 and VP7) capsid proteins (van Zyl et al., 2016). The pEAQ-HT vector allows the expression of VLPs and CLPs in plant expression system. This is a more flexible approach to express recombinant BTV VLPs, which were aggregated in paracrystalline arrays in the cytoplasm of plant cells (van Zyl et al., 2016).

\subsection{DIVA (differentiating infected from vaccinated animals) and vaccination}

The vaccine should act in such a way that infected and vaccinated animals should be differentiated easily (Table 4). The attenuated live vaccine viruses usually replicate in host body. Therefore, the antibody raised in infected and vaccinated animals cannot be differentiated. However, for inactivated vaccines several ELISA formats are in progress to detect non-structural (NS1, NS2 and NS3) proteins. Such approach is called DIVA strategy, where antibodies against non-structural proteins in sera of animals immunized with inactivated vaccine are either completely absent or present at very low titer. The subunit vaccine can also be used for DIVA strategy. A subunit vaccine having VP2 protein of BTV8 and NS1 and NS2 protein of BTV2 with an immune-stimulating complex (ISCOM) matrix adjuvant elicit differential level of antibody against VP7 protein in vaccinated and infected 
Table 4. DIVA strategy vaccines for bluetongue disease

\begin{tabular}{|c|c|c|c|}
\hline DIVA strategy & Particulars & Remarks & Reference \\
\hline NS3-ELISA & $\begin{array}{l}\text { Recombinant NS3 protein of BTV4/22045/PT04 } \\
\text { strain expressed in E. coli strain JM109 using } \\
\text { expression vector pET-28a was used as antigen for } \\
\text { ELISA. }\end{array}$ & $\begin{array}{l}\text { Cattle and sheep vaccinated with bivalent inactivated } \\
\text { BTV 2,4 vaccine didn't develop NS3 specific } \\
\text { antibody in ELISA. }\end{array}$ & Barros et al., 2009 \\
\hline VP7-ELISA & $\begin{array}{l}\text { The VP7 protein based subunit vaccine against BTV8 } \\
\text { for differentiation between vaccinated and infected } \\
\text { animals developed. }\end{array}$ & $\begin{array}{l}\text { VP7 seroconversion in cattle was observed after } \\
\text { natural infection, but not after experimental } \\
\text { vaccination regardless of BTV serotype. }\end{array}$ & $\begin{array}{l}\text { Anderson et al., } \\
2013,2014\end{array}$ \\
\hline $\begin{array}{l}\text { Segment } 10 \\
\text { genetic DIVA }\end{array}$ & $\begin{array}{l}\text { Eight silent mutations in genome segment } 10 \text { of BTV } \\
\text { were generated by reverse genetics. The modified } \\
\text { virus was used as modified live vaccine. }\end{array}$ & $\begin{array}{l}\text { These mutations are not detected by a segment } 10 \\
\text { pan BTV PCR test. However, BTV infected animals } \\
\text { can be easily diagnosed with segment } 10 \text { pan BTV } \\
\text { PCR test (DIVA-test). }\end{array}$ & van Rijn et al., 2013 \\
\hline $\begin{array}{l}\text { NS3/NS3a } \\
\text { knockout }\end{array}$ & $\begin{array}{l}\text { A NS3/NS3a knockout vaccine based on the } \\
\text { backbone of laboratory adapted strain of BTV1, } \\
\text { avirulent BTV6 or virulent BTV8 was prepared. }\end{array}$ & $\begin{array}{l}\text { The lack of NS3/NS3a expression in vaccine enables } \\
\text { the differentiation of infected from vaccinated } \\
\text { animals. }\end{array}$ & Feenstra et al., 2014b \\
\hline DISA vaccine & $\begin{array}{l}\text { Live BTV vaccine lacking NS3/NS3a protein } \\
\text { prepared. }\end{array}$ & $\begin{array}{l}\text { The NS3-specific competitive ELISA (NS3 cELISA) } \\
\text { enable the differentiation of vaccinated and infected } \\
\text { animals. }\end{array}$ & Tacken et al., 2015 \\
\hline
\end{tabular}

(challenged) animals. The differential level of VP7 antibodies detection in vaccinated and infected (challenged) animals suggests the DIVA compatibility of vaccine (Anderson et al., 2014). However, such approach is still under progress and no sustainable data is available to support it.

Live modified viruses can also be used for DIVA strategy. BTV non-structural proteins NS3/NS3a are essential for virus release from insect cells in vitro; however, they are not essential for virus replication. The live attenuated virus BTV6 and 8 without NS3/NS3a protein is non-virulent, gave protection against challenge infection without viremia in sheep. Upon DIVA analysis using ELISA, vaccinated sheep will show negative result for NS3 antibodies, whereas infected animal will show positive result (Feenstra et al., 2014a). Another DIVA approach using modified virus vaccines such as CLPs (VP3 and VP7) or VLPs (VP2, 3, 5 and 7) have also been in use. The vaccinated animals will have antibodies against certain protein available in VLPs or CLPs only. The detection of antibodies in animals against other than these proteins may differentiate the infected and vaccinated animals. Alternatively, virus vector vaccine against VP2 gene of BTV can also be used (Boone et al., 2007). Other molecular techniques such as PCR and qPCR can also be used to differentiate the segment 2, 5, 6 and 10 of vaccine and field BTV isolate (Monaco et al., 2006; Toussaint et al., 2007).

\subsection{Recombinant viral vector vaccines}

Recombinant viral vector vaccines are using an attenuated virus to introduce microbial DNA to the cells of the body. These are recombinant vaccines, where recombinant viruses carry BTV antigen-specific genes for their expression in the host (Table 5). The viral vectors (carrier viruses) used for this purpose are considered safe because they are attenuated. Moreover, they possess BTV antigen-specific genes (transgenes) without any molecular regulatory elements of the parental BTV. Thus, it greatly reduces the risk of gene segment reassortment with field BTV strains. Viruses, which can express VP2 gene of BTV, such as capripox, canarypox, vaccinia and herpes virus have been utilised for preparation of recombinant viral vector vaccine with different level of success (Boone et al., 2007; Savini et al., 2008; Franceschi et al., 2011; Ma et al., 2012).

\subsubsection{Herpesviruses}

Herpesviruses have dsDNA genome, which can accommodate large size of transgene insert. Recombinantvectored vaccines against VP2 and VP5 gene of BTV8 were developed using equine herpes viruses construct. These vaccines provided only partial protection during challenge in experimental vaccination in IFNAR (-/-) mice (Ma et al., 2012). Similarly, VP2 gene of BTV was expressed in a non-pathogenic bovine herpes virus 4 strain, and a recombinant BoHV4 -VP2 construct was prepared. The IFNAR $(-/-)$ mouse used as an experimental model showed only partial protection from BoHV4 -VP2 construct (Franceschi et al., 2011).

\subsubsection{Adenovirus}

Recombinant adenovirus vectors can induce T cell immunity; hence they are used as potent vaccine candidates against several viral diseases. The replication-defective recombinant human adenovirus serotype 5 (Ad5) expressing VP2, VP7 or NS3 BTV proteins were used for vaccination trial in 
Table 5. Recombinant viral vector vaccines for bluetongue disease (Calvo-Pinilla et al., 2014)

\begin{tabular}{|c|c|c|c|c|}
\hline $\begin{array}{l}\text { Viral vector used for } \\
\text { delivery }\end{array}$ & $\begin{array}{l}\text { BTV serotype and } \\
\text { proteins expressed }\end{array}$ & $\begin{array}{l}\text { Protection against } \\
\text { homologous virus }\end{array}$ & $\begin{array}{l}\text { Protection against } \\
\text { heterologous virus }\end{array}$ & $\begin{array}{l}\text { Vaccine tested } \\
\text { in species }\end{array}$ \\
\hline Bovine herpes virus & BTV8 VP2 & Partial & Not analyzed & $\operatorname{IFNAR}(-/-)$ mice \\
\hline Equine herpes virus & BTV8 VP2 & No & Not analyzed & $\operatorname{IFNAR}(-/-)$ mice \\
\hline Equine herpes virus & BTV8 VP2, VP5 & Partial & Not analyzed & $\operatorname{IFNAR}(-/-)$ mice \\
\hline MVA virus & BTV4 VP2, VP5 & Partial & Not analyzed & $\operatorname{IFNAR}(-/-)$ mice \\
\hline MVA virus & BTV4 VP2, VP5, VP7 & Complete & No & $\operatorname{IFNAR}(-/-)$ mice \\
\hline MVA virus & BTV4 VP2, VP5, VP7 & Complete & Complete & $\operatorname{IFNAR}(-/-)$ mice \\
\hline MVA virus & BTV4 VP7, NS1 & Partial & Partial & $\operatorname{IFNAR}(-/-)$ mice \\
\hline MVA virus & BTV8 VP2, VP5, VP7 & Complete & Not analyzed & $\operatorname{IFNAR}(-/-)$ mice \\
\hline MVA virus & BTV8 VP2 & Complete & Not analyzed & $\operatorname{IFNAR}(-/-)$ mice \\
\hline MVA virus & BTV4 VP2, VP7, NS1 & Not analyzed & Partial & sheep \\
\hline Capripox virus & BTV1 VP7 & Not analyzed & Partial & sheep \\
\hline Capripox virus & BTV2 VP2, VP7, NS1, NS3 & Partial & Not analyzed & sheep \\
\hline Canary pox virus & VP2, VP5 & Complete & Not analyzed & sheep \\
\hline Vaccinia virus WR & $\mathrm{VP} 2$ & Partial & Not analyzed & sheep \\
\hline Vaccinia virus WR & VP2, VP5 & Partial & Not analyzed & sheep \\
\hline
\end{tabular}

BTV: Bluetongue virus; MVA: Modified vaccinia virus Ankara.

IFNAR(-/-) mice and sheep (Martín et al., 2015). The mice vaccinated with different $\mathrm{rAd} 5$ showed complete protection against BTV challenge as evidenced by humoral as well cellular (BTV-specific CD8+- and CD4+-T cell) immune response. However, sheep showed mild disease symptoms and reduced viremia after vaccination with Ad5-BTV-VP2 and Ad5-BTV-VP7 or only with Ad5-BTV-VP7 followed by BTV challenge (Martín et al., 2015). Sheep vaccinated with Ad5-BTV-VP7 elicited sufficient BTV-specific CD8+ T cell response but no neutralizing antibodies response.

In other study, the VP7 core protein of BTV2 was expressed either in a non-replicative canine adenovirus type 2 (Cav-VP7 $\mathrm{R}^{0}$ ) or a leporipoxvirus (SG33-VP7) to elicit immune response in sheep (Bouet-Cararo et al., 2014). Both of the recombinant antigens elicited the humoral immune response in sheep. Although both SG33-VP7 and Cav-VP7 $\mathrm{R}^{0}$ stimulated sufficient antigen-specific CD4+ response, only Cav-VP7 $\mathrm{R}^{0}$ significantly stimulated the antigen-specific CD8+ cells. Later on, Cav-VP7 R ${ }^{0}$ vaccine-immunized sheep were challenged with either homologous serotype BTV2 or the heterologous BTV8. The viremia estimation by real-time PCR in plasma showed that the immune response triggered by Cav-VP7 $\mathrm{R}^{0}$ was insufficient to provide protective immunity against BTV (Bouet-Cararo et al., 2014). It only generated partial protection against homologous serotype. It indicates the need for further study of the role of BTV core proteins in cross-protective immune response.

\subsubsection{Poxviruses}

Poxviruses replicate in the cytoplasm of infected cells, hence they eliminate the risk of genomic integration in host
DNA and virus persistence. They can also accommodate large fragments of foreign DNA. Several members of Poxviridae family such as canarypox, capripox and vaccinia viruses have been used for expression of BTV antigens.

\subsubsection{Capripox}

The capripox virus has been used as carrier for BTV gene for vaccine preparation. The VP7 gene of BTV1 strain (BTV1SA strain) from South Africa was expressed in a recombinant capripox virus (rCPV.BTV1.VP7). This recombinant vaccine elicits partial cross-protection against a lethal dose of BTV3. The partial cross-protection was probably observed due to cell-mediated immunity against VP7 (Wade-Evans et al., 1996). Other attempts for expression of BTV2 proteins such as VP2, VP7, NS1 and NS3 in recombinant capripox viruses were also made (Perrin et al., 2007). However, vaccination of animals with VP2, VP7 or NS3 recombinant vaccine only developed humoral immune response. Thus, this vaccine only partially elicited the immune response against homologous BTV challenge.

\subsubsection{Canary pox virus}

Canary pox virus is a dsDNA enveloped virus of the Poxviridae family. The large genome size $(365 \mathrm{kbp})$ of canary pox virus (CNPV) can easily accommodate foreign genes. The CNPV expression system is advantageous because it undergoes abortive infection. However, it expresses the necessary antigens to elicit sufficient immune response in hosts system (Tulman et al., 2004). The recombinant canary pox virus was also used as an expression system for VP2 and VP5 proteins of BTV17. Upon challenge infection, none of the vaccinated animals showed viremia or clinical signs of BT (Boone et al., 2007). 


\subsubsection{Vaccinia virus}

The WR strain of vaccinia virus was used for expression of either VP2 alone (VV-VP2) or both VP2 and VP5 (VVVP2-VP5) of Australian BTV1 for recombinant vaccine preparation (Lobato et al., 1997). The vaccination induced only partial protection against homologous virus in sheep. The viremia was observed in $66 \%$ of sheep vaccinated with VV-VP2-VP5 construct. However, VV-VP2 construc-vaccinated sheep did not show any viremia (Lobato et al., 1997).

\subsubsection{Modified vaccinia virus Ankara}

Modified vaccinia virus Ankara (MVA) is also used as vaccine vector for high level of expression of foreign proteins (Carroll et al., 1997). The recombinant MVAs (rMVAs) are used as vectors to generate vaccines against several viral pathogens. Originally this virus was obtained from Chorioallantois vaccinia virus Ankara and passaged over 570 times in cell culture. Thus, it lost $15 \%$ of its parental genome and became replication-deficient in most mammalian as well as human cells (Esteban, 2009). The recombinant MVA (rMVA) induces both humoral and cell-mediated immunity in host (Ramirez et al., 2000). The rMVA has been used to construct several vaccines expressing different BTV-specific proteins from several BTV serotypes. The recombinant vector vaccine against VP2 and VP5 protein of BTV4 was developed using rMVA. The IFNAR (-/-) mice vaccinated with rMVA-VP2VP5 elicit high level of protective immunity against homologous serotype (Calvo-Pinilla et al., 2009; 2012). Similarly, rMVAs were also generated to express the VP2, VP7 and NS1 proteins of BTV4 (Marín-López and Ortego, 2016).

Recently, a new recombinant BTV vaccine candidate was engineered using VP2, VP7 and NS1 protein of BTV serotype 4 (Marín-López et al., 2017). These proteins were incorporated into recombinant modified vaccinia virus Ankara (rMVA) and avian reovirus muNS-Mi microspheres (MS-VP2/VP7/NS1). The combined effect of these two antigens elicited adequate levels of neutralizing antibodies in IFNAR(-/-) mice and increased the ratio of IgG2a/IgG1 in sera, which indicates the induction of a Th1 and CD8 T cell response (Marín-López et al., 2017). The post immunization challenge with homologous BTV serotype 4 and heterologous BTV serotype 1 showed adequate protection.

\subsection{DNA vaccines}

DNA vaccines consist of microbial DNA that is directly administered into host body. They are administered to host body through a needle and syringe or using high pressure to shoot gold particles coated with DNA directly into cells. These vaccines have advantages of easy manufacturing, safety, cost effectiveness and biological stability. The VP2, VP7 and NS1 proteins from BTV4 expressed in plasmid vector showed only partial protection in IFNAR(-/-) mice dur- ing homologous virus challenge (Calvo-Pinilla et al., 2014). Although this vaccine did not show any clinical protection, viremia was delayed in DNA-BTV-vaccinated animals. The DNA vaccines often showed lower immunogenicity, thus they can be used as a boosting agent for immune system along with heterologous vaccination regimes (Calvo-Pinilla et al., 2009, 2012; Jabbar et al., 2013).

Another approach of prime DNA vaccination along with booster recombinant vaccine was also practiced in sheep. The DNA vaccine and recombinant fowl pox virus (rFPV) vaccine co-expressing VP2 and VP5 proteins or VP2 in combination with VP5 or VP2 alone of BTV1 were evaluated for successful vaccination (Li et al., 2015). The best strategy for sheep was validated as combined prime DNA vaccine consisting of a plasmid pCAG-(VP2+VP5), co-expressing VP2 and VP5 followed by an rFPV-(VP2+VP5) vaccine boost (co-expressing VP2 and VP5). This combination elicits high titer of neutralizing antibodies against BTV1 in sheep (Li et al., 2015).

\subsection{DISC (disabled infectious single cycle) vaccines}

DISC vaccines of BTV allow the virus to infect the vaccinated host animal without completing the replication cycle. This vaccine approach is based on production of modified virus using gene deletion technique, which selectively deletes BTV replication-specific gene(s). It results in expression of BTV antigenic proteins at natural sites of infection without the production of infectious viral particle or disease in host animal. Thus, it is a form of extreme level of attenuation. The DISC vaccines possess several safety features of inactivated vaccines. However, they also act like live attenuated vaccine because they express the viral antigenic proteins at sites of infection. DISC vaccines have exciting future potential as safe BTV vaccine (Roner and Joklik, 2001; Coleman et al., 2008). The replication-deficient DISC BTV has been recently prepared using reverse genetics technology (Boyce et al., 2008). The replication-deficient nature of the virus was introduced through insertion of a lethal mutation in gene encoding viral helicase VP6 protein (Matsuo et al., 2011). The replication-defective BTV1 DISC virus was allowed for reassortment with vp2 and vp5 gene of BTV8, creating a new replication-deficient reassortant virus BTV1/8D1. The vaccination of sheep using these BTV 1 and BTV1/8D1 DISC viruses showed absence of viremia after challenge with homologous BTV1 or BTV8, respectively. The further study showed that combination of DISC viruses using antigenic genes from BTV2, 4 and 8 elicit protective immune response against homologous virus without any viremia and clinical signs (Celma et al., 2013). For BTV control, DISC vaccine can be used as next-generation vaccination strategy. The MultiDISC vaccine trial containing cocktail of six BTV serotypes $1,2,4,8,13$ and 21 was successfully made in sheep (Celma 
et al., 2017). The MultiDISC vaccine elicited the complete protective immune response both in early virulent virus challenge, as well as 5 months post-vaccination challenge, against individual BTV serotypes. However, triDISC vaccine (BTV2, 4 and 8) elicited somewhat lesser protection in cattle than in sheep (Celma et al., 2017).

\subsection{DISA (disabled infectious single animal) vaccines}

DISA vaccines are replicating, highly protective and non-pathogenic vaccines, which do not cause viremia in host animal. The NS3/NS3a protein is required for release of BTV from infected host cells. However, it is essentially not required for in vitro virus replication. The deletions in NS3/NS3a gene allow minimal multiplication of BTV in vaccinated animal. The deletion of NS3/NS3a leads to hindrance in BTV release from infected mammalian cells and also reduces the virus uptake by Culicoides vector and further release from insect cells (Feenstra et al., 2015a). However, the minimal multiplication allows the expression of BTV antigenic protein, which is essential for immune response. BTV knockout without NS3/NS3a segment can elicit immune response in sheep without causing viremia. A next generation vaccine having NS3/NS3a deletion in avirulent BTV6 or virulent BTV8 and laboratory-adapted strain of BTV1 was used for vaccination in sheep (Feenstra et al., 2014b). A challenge infection with respective serotypes at 3 weeks post vaccination showed protective immunity. However, no viremia was detected using sensitive molecular diagnosis. Moreover, lack of NS3/NS3a expression also enables the differentiation of BT-infected from vaccinated animals. Thus, DISA vaccine can also be used in DIVA strategy for monitoring and surveillance of virus spread in livestock.

Further advancement in DISA vaccine was made using exchange of VP2 of laboratory strain of BTV1 with VP2 of European viruses BTV2, 4, 8, 9 and 16 using reverse genetics. The VP2 exchange was combined with NS3/NS3a-negative phenotype in BTV1. This strategy did not make much effect on virus growth. The DISA vaccine having chimeric BTV1/16 VP2 elicits immune response against BTV1 and BTV16 in sheep. Thus, DISA vaccine may elicit protective immune response for both the parental serotypes in chimeric VP2 (Feenstra et al., 2015b). Recently, DISA vaccine was developed for BTV serotype 8 using live attenuated virus devoid of non-structural NS3/NS3a protein. The intramuscular administration of this vaccine elicited the optimum immune response (IgG antibodies) against VP7, which persisted for longer time (van Rijn et al., 2017).

\subsection{Use of reverse genetics for vaccine development}

Traditional live attenuated or inactivated vaccines have several limitations, which may cause adverse effect in host animals. The recent development in molecular biology has opened new insight for development of live attenuated vaccines through reverse genetics approach. Each genome segment of BTV can be cloned individually and several transcripts of each segment can be prepared. The infectious virion particle can be produced from these clones using one transcript for each segment in vitro to transfect permissive cells (Harper et al., 2006). This approach also allows the introduction of any mutation into BTV genome, as long as the resulting virus is viable. The study of virulence of BTV mutants and their pathogenicity in ruminant host allow the design of newer vaccine strains having multiple attenuating mutations. Moreover, BTV inclusion particle and reverse genetics study also revealed that phylogenetically distinct outer capsid proteins (VP2 and VP5) from different serotypes can be assembled on the conserved core proteins of other serotype to create viable BTV particle (Boyce et al., 2008). A synthetic chimera BTV was generated using VP2 protein having regions derived from both BTV1 and BTV8. This chimera virus showed neutralization by both BTV1 and BTV8 antiserum. Thus, chimera viruses can also be used as BT vaccines (Nunes et al., 2014). This approach suggests that a new vaccine virus can be prepared using outer capsid antigen-specific gene of serotypes of interest.

\subsection{Gene segment reassortant vaccines}

Reverse genetics can also be used for exchange of vp2 and vp5 gene of live attenuated BTV6 vaccine with those of BTV1 and 8. It results in generation of reassortant BTVac1 and BTVac8 virus, respectively (van Gennip et al., 2012). Sheep vaccinated with a single dose of these reassortant viruses elicit neutralizing antibody response against homologous serotype and they showed nearly no clinical sign after challenge with virulent strain of BTV8. Thus, these studies suggested the tremendous potential of reverse genetics in vaccine development. However, further work is needed to explore the future potential of this strategy and also the bio safety risk assessment related to exchange of gene segments between field and vaccine viruses.

\section{Conclusion and future perspective}

The epidemiological study of BTV worldwide shows the risk of BTV to entire world as emerging infectious disease. BT also hinders the trade of livestock and its products because import of livestock and its product from BT-endemic to BT-free countries are banned. However, control of BT through relevant and timely vaccination is feasible. Although the conventional vaccines such as live attenuated and inactivated vaccines are effective, they have some serious limitations. To overcome the limitations of conventional 
vaccines, new generation (modern) vaccine approaches such as recombinant, subunits, VLPs/CLPs, virus-vectored vaccines, etc. can be utilised for controlling the BT infection. The new generation vaccines have inherent safety features in comparison to conventional vaccines. Some of the recombinant vaccines have been designed to express the conserved protective antigens of BTV. Such approach may generate an effective multivalent vaccine against several BTV serotypes that would reduce the requirement of vaccination against individual serotypes or the number of multiserotype vaccinations. Thus, cross-protecting recombinant vaccines against several BTV serotypes are of particular interest in $B T$ vaccination. The new generation vaccines may also allow the BT control along with its surveillance. The experimental new generation vaccine may also be used as a molecular tool to understand the immune system mechanism during BT infection. Despite several approaches of production of newgeneration vaccines, they are mostly effective under in house conditions. Their large-scale field testing for efficacy and safety is required. Several new generation vaccines possess the possibility to serologically differentiate the vaccinated animals from infected ones.

Acknowledgment. Authors are thankful to college of veterinary and Animal Sciences, SVP University of Agriculture and Technology, Meerut for providing infrastructure facility to prepare the manuscript.

\section{References}

Anderson J, Hägglund S, Bréard E, Comtet L, Lövgren Bengtsson K, Pringle J, Zientara S, Valarcher JF, Clin. Vaccine Immunol. 20, 1115-1122, 2013. https://doi.org/10.1128/ CVI.00229-13

Anderson J, Hägglund S, Bréard E, Riou M, Zohari S, Comtet L, Olofson AS, Gélineau R, Martin G, Elvander M, Blomqvist G, Zientara S, Valarcher JF, Vaccine 32, 66146621, 2014. https://doi.org/10.1016/j.vaccine.2014.09.066

Balam D, Daggupati S, Maddireddy H, Vet. World. 4, 444-448, 2011. https://doi.org/10.5455/vetworld.2011.444-448

Barr E, Tamms G, Clin. Infect. Dis. 45,609-617, 2007. https://doi. org/10.1086/520654

Barros SC, Cruz B, Luís TM, Ramos F, Fagulha T, Duarte M, Henriques M, Fevereiro M, Vet. Microbiol. 137, 252-259, 2009. https://doi.org/10.1016/j.vetmic.2009.01.033

Belhouchet M, Mohd Jaafar F, Firth AE, Grimes JM, Mertens PP, Attoui H, PLoS One 6, e25697, 2011. https://doi. org/10.1371/journal.pone.0025697

Berry LJ, Osburn BI, Stott JL, Farver T, Heron B, Patton W, Vet. Res. Commun. 5, 289-293, 1982. https://doi.org/10.1007/ BF02214996

Bhanuprakash V, Indrani BK, Hosamani M, Balamurugan V, Singh RK, Expert Rev. Vaccines 8, 191-204, 2009. https://doi. org/10.1586/14760584.8.2.191
Bommineni YR, Reddy YN, Rao PP, Sudheer D, Susmitha B, Sharma BJ, Rao MV, Vet. Rec. 163, 545-546, 2008. https://doi. org/10.1136/vr.163.18.545

Boone JD, Balasuriya UB, Karaca K, Audonnet JC, Yao J, He L, Nordgren R, Monaco F, Savini G, Gardner IA, Maclachlan NJ, Vaccine 25,672-678, 2007. https://doi.org/10.1016/j. vaccine.2006.08.025

Bouet-Cararo C, Contreras V, Caruso A, Top S, Szelechowski M, Bergeron C, Viarouge C, Desprat A, Relmy A, Guibert JM, Dubois E, Thiery R, Bréard E, Bertagnoli S, Richardson J, Foucras G, Meyer G, Schwartz-Cornil I, Zientara S, Klonjkowski B, PLoS One 9, e111605, 2014. https://doi. org/10.1371/journal.pone.0111605

Boyce M, Celma CP, Roy P, J. Virol. 82, 8339-8348, 2008. https:// doi.org/10.1128/JVI.00808-08

Breard E, Belbis G, Viarouge C, Nomikou K, Haegeman A, De Clercq K, Hudelet P, Hamers C, Moreau F, Lilin T, Durand B, Mertens P, Vitour D, Sailleau C, Zientara S, Vaccine 33, 512-518, 2015. https://doi.org/10.1016/j. vaccine.2014.11.053

Breard E, Pozzi N, Sailleau C, Durand B, Catinot V, Sellem E, Dumont P, Guerin B, Zientara S, Vet. Record. 160, 431-435, 2007. https://doi.org/10.1136/vr.160.13.431

Browne JG, Adv. Vet. Sci. Comp. Med. 15, 1-46, 1971.

Browne JG, Jones RH, Virology 30, 127-133, 1966. https://doi. org/10.1016/S0042-6822(66)81016-4

Burgin LE, Gloster J, Sanders C, Mellor PS, Gubbins S, Carpenter S, Transbound Emerg. Dis. 60(3), 263-272, 2012. https:// doi.org/10.1111/j.1865-1682.2012.01345.x

Calvo-Pinilla E, Castillo-Olivares J, Jabbar T, Ortego J, de la Poza F, Marín-López A, Virus Res. 182, 78-86, 2014. https:// doi.org/10.1016/j.virusres.2013.11.013

Calvo-Pinilla E, Navasa N, Anguita J, Ortego J, PLOS One 7, e34735, 2012. https://doi.org/10.1371/journal.pone.0034735

Calvo-Pinilla E, Rodriguez-Calvo T, Sevilla N, Ortego J, Vaccine 28, 437-445, 2009. https://doi.org/10.1016/j.vaccine.2009.10.027

Campbell CH, Vaccine 3, 401, 1985. https://doi.org/10.1016/0264$\underline{410 X(85) 90131-8}$

Caporale V, Giovannini A, Rev. Sci. Tech. 29, 573-591, 2010. https:// doi.org/10.20506/rst.29.3.2001

Carpi G, Holmes EC, Kitchen A, J. Mol. Evol. 70, 583-592, 2010. https://doi.org/10.1007/s00239-010-9354-y

Carroll MW, Overwijk WW, Chamberlain RS, Rosenberg SA, Moss B, Restifo NP, Vaccine 15, 387-394, 1997. https://doi. org/10.1016/S0264-410X(96)00195-8

Celma CC, Boyce M, van Rijn PA, Eschbaumer M, Wernike K, Hoffmann B, Beer M, Haegeman A, De Clercq K, Roy P, J. Virol. 87, 9856-9864, 2013. https://doi.org/10.1128/ JVI.01514-13

Celma CC, Stewart M, Wernike K, Eschbaumer M, GonzalezMolleda L, Breard E, Schulz C, Hoffmann B, Haegeman A, De Clercq K, Zientara S, van Rijn PA, Beer M, Roy P, J. Virol. 91, e01892-16, 2017. https://doi.org/10.1128/ JVI.01892-16

Coetzee P, Stokstad M, Venter EH, Myrmel M, Van Vuuren M, Virol. J. 9,198, 2012. https://doi.org/10.1186/1743-422X-9-198 
Coleman JR, Papamichail D, Skiena S, Futcher B, Wimmer E, Mueller S, Science. 320, 1784-1787, 2008. https://doi. org/10.1126/science.1155761

Dadawala AI, Kher HS, Chandel BS, Bhagat AG, Chauhan HC, Ranjan K, Minakshi P, Adv. Anim. Vet. Sci. 1 (4S), 24-29, 2013.

Dungu BK, Louw I, Potgieter C, von Teichman BF, Open Vet. Sci. J. 2,130-133, 2008. https://doi.org/10.2174/187431880800 $\underline{2010130}$

DuToit RM, Onderstepoort J. Vet. Sci. Anim. Indust. 19, 7-16, 1944.

Eaton BT, Gould AR, Hyatt AD, Coupar SEN, Martyn JC, White JR, Virolology 18, 687, 1990.

Emidio B, di Nicolussi P, Patta C, Ronchi GF, Monaco F, Savini G, Ciarelli A, Caporale V, Vet. Ital. 40, 640-644, 2004.

Esteban M, Hum. Vaccine 5, 867-871, 2009. https://doi. org $/ 10.4161 /$ hv. 9693

European commission, http://ec.europa.eu/food/fs/sc/scah/ out47_en.pdf, 2000.

Feenstra F, Drolet BS, Boonstra J, van Rijn PA, Parasit. Vectors 8,476, 2015a. https://doi.org/10.1186/s13071-015-1063-3

Feenstra F, Maris-Veldhuis M, Daus FJ, Tacken MG, Moormann RJ, van Gennip RG, van Rijn PA, Vaccine 32, 7108-7114, 2014a. https://doi.org/10.1016/j.vaccine.2014.10.033

Feenstra F, Pap JS, van Rijn PA, Vaccine 33, 812-818, 2015b. https:// doi.org/10.1016/j.vaccine.2014.12.003

Feenstra F, van Gennip RG, Maris-Veldhuis M, Verheij E, van Rijn PA, J. Gen. Virol. 95(Pt 9), 2019-2029, 2014b. https://doi. org/10.1099/vir.0.065615-0

Feenstra F, van Rijn PA, Crit. Rev. Microbiol. 43, 142-155, 2017. https://doi.org/10.1080/1040841X.2016.1186005

Firth C, Blasdell KR, Amos-Ritchie R, Sendow I, Agnihotri K, Boyle DB, Daniels P, Kirkland PD, Walker PJ, Vet. Res. 48, 82, 2017. https://doi.org/10.1186/s13567-017-0488-4

Franceschi V, Capocefalo A, Calvo-Pinilla E, Redaelli M, MucignatCaretta C, Mertens P, Ortego J, Donofrio G, Vaccine 29 (16), 3074-3082, 2011. https://doi.org/10.1016/j.vaccine.2011.01.075

Franchi P, Mercante MT, Ronchi GF, Armillotta G, Ulisse S, Molini U, Di Ventura M, Lelli R, Savini G, Pini A, J. Virol. Methods. 153, 263-265, 2008. https://doi.org/10.1016/j. jviromet.2008.07.007

French TJ, Marshall JJ, Roy P, J. Virol. 64, 5695-5700, 1990.

French TJ, Roy P, J Virol. 64, 1530-1536, 1990.

Gould AR, Martyn JC, Stevenson L, Virus Res. 31, 291-303, 1994. https://doi.org/10.1016/0168-1702(94)90023-X

Hammoumi S, Breard E, Sailleau C, Russo P, Grillet C, CetreSossah C, Albina E, Sanchis R, Pepin M, Guibert J-M, Zientara S, J. Vet. Med. B. 50, 316-321, 2003. https://doi. org/10.1046/j.1439-0450.2003.00682.x

Harper DM, Franco EL, Wheeler CM, Moscicki AB, Romanowski B, Roteli-Martins CM, Jenkins D, Schuind A, Costa Clemens SA, Dubin G, HPV Vaccine Study group, Lancet 367, 1247-1255, 2006. https://doi.org/10.1016/S01406736(06)68439-0

Hassan SH, Roy P, J. Virol. 73, 9832-9842, 1999.

Hassan SH, Wirblich C, Forzan M, Roy P, J. Virol. 75, 8356-8367, 2001. https://doi.org/10.1128/JVI.75.18.8356-8367.2001
He CQ, Ding NZ, He M, Li SN, Wang XM, He HB, Liu XF, Guo HS, J. Virol. 84, 11487-11495, 2010. https://doi.org/10.1128/ JVI.00889-10

Hemadri D, Maan S, Chanda MM, Rao PP, Putty K, Krishnajyothi Y, Reddy GH, Kumar V, Batra K, Reddy YV, Maan NS, Reddy YN, Singh KP, Shivachandra SB, Hegde NR, Rahman H, Mertens PPC, Transbound. Emerg Dis. 64, 1912-1917, 2017. https://doi.org/10.1111/tbed.12589

Hofmann MA, Renzullo S, Mader M, Chaignat V, Worwa G, Emerg. Infect. Dis. 14, 1855-1861, 2008. https://doi.org/10.3201/ eid1412.080818

Huismans H, van der Walt NT, Cloete M, Erasmus BJ, Virology 157, 172-179, 1987. https://doi.org/10.1016/00426822(87)90326-6

Hyatt AD, Zhao Y, Roy P, Virology 193, 592-603, 1993. https://doi. org/10.1006/viro.1993.1167

Jabbar TK, Calvo-Pinilla E, Mateos F, Gubbins S, Bin-Tarif A, Bachanek-Bankowska K, Alpar O, Ortego J, Takamatsu HH, Mertens PP, Castillo-Olivares J, PLoS One 8,e60574, 2013. https://doi.org/10.1371/journal.pone.0060574

Jenckel M, Bréard E, Schulz C, Sailleau C, Viarouge C, Hoffmann B, Höper D, Beer M, Zientara S, Genome Announc. 3, pii: e00016-15, 2015. https://doi.org/10.1128/genomeA.00016-15

Krishnajyothi Y, Maan S, Kandimalla K, Maan NS, Tutika RB, Reddy YV, Kumar A, Mrunalini N, Reddy GH, Putty K, Ahmed SM, Reddy YN, Hemadri D, Singh KP, Mertens PP, Hegde NR, Rao PP, Transbound. Emerg. Dis. 63, 360-364, 2016. https://doi.org/10.1111/tbed.12512

Legisa DM, Perez Aguirreburualde MS, Gonzalez FN, Marin-Lopez A, Ruiz V, Wigdorovitz A, Martinez-Escribano JA, Ortego J, Dus Santos MJ, Vaccine 33, 2614-2619, 2015. https:// doi.org/10.1016/j.vaccine.2015.03.067

Li J, Yang T, Xu Q, Sun E, Feng Y, Lv S, Zhang Q, Wang H, Wu D, Appl. Microbiol. Biotechnol. 99, 8643-8652, 2015. https:// doi.org/10.1007/s00253-015-6697-8

Lobato ZI, Coupar BE, Gray CP, Lunt R, Andrew ME, Vet. Immunol. Immunopathol. 59, 293-309, 1997. https://doi. org/10.1016/S0165-2427(97)00084-6

Loudon PT and Roy P, Virology 191, 231-236, 1992. https://doi. org/10.1016/0042-6822(92)90184-Q

Ma G, Eschbaumer M, Said A, Hoffmann B, Beer M, Osterrieder N, PLoS One 7, e34425, 2012. https://doi.org/10.1371/ journal.pone.0034425

Maan S, Maan NS, Belaganahalli MN, Rao PP, Singh KP, Hemadri D, Putty K, Kumar A, Batra K, Krishnajyothi Y, Chandel BS, Reddy GH, Nomikou K, Reddy YN, Attoui H, Hegde NR, Mertens PP, PLoS One 10, e0131257, 2015. https:// doi.org/10.1371/journal.pone.0131257

Maan S, Maan NS, Pullinger G, Nomikou K, Morecroft E, Guimera M, Belaganahalli MN, Mertens PPC, J. Virol. 86, 59715972, 2012. https://doi.org/10.1128/JVI.00596-12

Maan S, Maan NS, Samuel AR, Rao S, Attoui H, Mertens PPC, J. Gen. Virol. 88, 621-630, 2007. https://doi.org/10.1099/ vir.0.82456-0

Marín-López A, Calvo-Pinilla E, Barriales D, Lorenzo G, Benavente J, Brun A, Martínez-Costas JM, Ortego J, Antiviral 
Res. 142, 55-62, 2017. https://doi.org/10.1016/j.antiviral.2017.03.010

Marín-López A, Ortego J, Methods Mol. Biol. 1349, 137-150, 2016. https://doi.org/10.1007/978-1-4939-3008-1_9

Marín-López A, Otero-Romero I, de la Poza F, Menaya-Vargas R, Calvo-Pinilla E, Benavente J, Martínez-Costas JM, Ortego J, Antiviral Res. 110, 42-51, 2014. https://doi. org/10.1016/j.antiviral.2014.07.008

Martín V, Pascual E, Avia M, Pe-a L, Valcárcel F, Sevilla N, PLoS One 10, e0143273, 2015. https://doi.org/10.1371/journal. pone. 0143273

Matsuo E, Celma CC, Boyce M, Viarouge C, Sailleau C, Dubois E, Breard E, Thiery R, Zientara S, Roy P, J. Virol. 85, 10213-10221, 2011. https://doi.org/10.1128/JVI.05412-11

Mehlhorn H, Walldorf V, Klimpel S, Schmahl G, Parasitol. Res. 103, 79-86, 2008. https://doi.org/10.1007/s00436-008-1100-7

Meiswinkel R, Baldet T, de Deken R, Takken W, Delecolle JC, Mellor PS, Prev. Vet. Med. 87, 55-63, 2008. https://doi. org/10.1016/j.prevetmed.2008.06.005

Melville LF, Weir R, Hunt N, Davis S, Walsh S, Vet. Ital. 51,263-267, 2015.

Mertens PPC, Brown F, Sanger DV, Virol. 135, 207-217, 1984. https://doi.org/10.1016/0042-6822(84)90131-4

Meyer G, Lacroux C, Léger S, Top S, Goyeau K, Deplanche M, Lemaire M, Emerg. Infect. Dis. 15, 608-610, 2009. https:// doi.org/10.3201/eid1504.081514

Minakshi P, Singh R, Ranjan K, Kumar P, Joshi CG, Reddy YK, Prasad G, J. Virol. 86, 8337-8338, 2012. https://doi. org/10.1128/JVI.01128-12

Modumo J, Venter EH, J. S. Afr. Vet. Assoc. 83, 17, 2012. https:// doi.org/10.4102/jsava.v83i1.17

Monaco F, Cammà C, Serini S, Savini G, Vet. Microbiol. 116, 45-52, 2006. https://doi.org/10.1016/j.vetmic.2006.03.024

Nason EL, Rothagel R, Mukherjee SK, Kar AK, Forzan M, Prasad BVV, Roy P, J. Virol. 78, 8059-8067, 2004. https://doi. org/10.1128/JVI.78.15.8059-8067.2004

Nunes SF, Hamers C, Ratinier M, Shaw A, Brunet S, Hudelet P, Palmarini M, J. Virol. 88(21), 12222-12232, 2014. https:// doi.org/10.1128/JVI.02183-14

OBP: https://www.obpvaccines.co.za/Cms_Data/Contents/ OBPDB/Folders/Product/ contents/GL4, 2GL73FYR4L9CU/2013\%20Bluetongue_PI.pdf, 2013.

OIE: Manual of Standards for Diagnostic Tests and Vaccines. 1996.

Owens RJ, Limn C, Roy P, J Virol. 78, 6649-6656, 2004. https://doi. org/10.1128/JVI.78.12.6649-6656.2004

Pandey AB, Nandi S, Dubey SC, Sonawane GG, Mondal B, BhanuprakashV, Audarya SD, Suresh I, Sharma K, Prasad G, Singh RK, Singh N, Chauhan RS, J. Immunol. Immunopathol. 8, 145-146, 2006.

Pathak KB, Biswas SK, Tembhurne PA, Hosamani M, Bhanuprakash V, Prasad G, Singh RK, Rasool TJ, Mondal B, J. Virol. Methods. 152, 6-12, 2008. https://doi.org/10.1016/j. jviromet.2008.06.010

Pawan Kumar, Prasad Minakshi, Ranjan K, Ravinder Dalal, Gaya Prasad, Adv. Anim. Vet. Sci.1, 14-19, 2013.

Perrin A, Albina E, Breard E, Sailleau C, Prome S, Grillet C, Kwiatek O, Russo P, Thiery R, Zientara S, Cetre-Sossah
C, Vaccine 25, 6774-6783, 2007. https://doi.org/10.1016/j. vaccine.2007.06.052

Prasad G, Malik P, Malik PK, Minakshi, Indian J. Virol. 14, 51-53, 1998.

Prasad G, Sreenivasulu D, Singh KP, Mertens PPC, Maan S, In Bluetongue. (Eds. Mellor P, Baylis M, Merten PC). Elsevier Ltd., London, pp.167-195, 2009. https://doi.org/10.1016/ B978-012369368-6.50012-5

Prasad M, Ranjan K, Kumar P, Prasad G, Vet. World. 6, 244-248, 2013. https://doi.org/10.5455/vetworld.2013.244-248

Rajkhowa S, Rajkhowa C, Dutta PR, Michui P, Das R, Rev. Sci. Tech. 27, 907-914, 2008. https://doi.org/10.20506/rst.27.3.1851

Ramakrishnan MA, Pandey AB, Singh KP, Singh R, Mehrotra ML, Vet. Ital. 41, 149-155, 2005.

Ramakrishnan MA, Pandey AB, Singh KP, Singh R, Nandi S, Mehrotra ML, Vet. Res. Commun. 30, 873-880, 2006. https://doi.org/10.1007/s11259-006-3313-5

Ramirez JC, Gherardi MM, Esteban M, J. Virol. 74 (2), 923-933, 2000. https://doi.org/10.1128/JVI.74.2.923-933.2000

Ranjan K, Minakshi P, Kumar P, Prasad G, Adv. Anim. Vet. Sci. 2, 91-97, 2014a. https://doi.org/10.14737/journal. aavs/2014/2.2.91.97

Ranjan K, Minakshi P, Prasad G, Acta Virol. 59, 317-337, 2015. https://doi.org/10.4149/av $201504 \quad 317$

Ranjan K, Prasad G, Kumar P, Minakshi P, Adv. Anim. Vet. Sci. 1, 30-36, 2013.

Ranjan K, Prasad G, Kumar P, Minakshi P, Adv. Anim. Vet. Sci. 2, 98-103, 2014b. https://doi.org/10.14737/journal. aavs/2014/2.2.98.103

Ranjan K, Prasad M, Brar B, Prasad G, Indian J. Comp. Microbiol. Immunol. Infect. Dis. 38, 16-21, 2017 a.

Ranjan K, Prasad M, Brar B, Prasad G, Indian J. Vet. Sci. Biotech. 12, 112-117, 2017b.

Reddy YKM, Manohar BM, Pandey AB, Reddy YN, Prasad G, Chauhan RS, Indian Vet. J. 87,434-436, 2010.

Reddy YV, Susmitha B, Patil S, Krishnajyothi Y, Putty K, Ramakrishna KV, Sunitha G, Devi BV, Kavitha K, Deepthi B, Krovvidi S, Reddy YN, Reddy GH, Singh KP, Maan NS, Hemadri D, Maan S, Mertens PP, Hegde NR, Rao PP, Transbound Emerg. Dis. 65, 547-556, 2018. https://doi. org/10.1111/tbed.12738

Roner MR, Joklik WK, Proc. Natl. Acad. Sci. USA. 98, 8036-8041, 2001. https://doi.org/10.1073/pnas.131203198

Roy P, FEMS Microbiol. Immunol. 2, 223-234, 1990. https://doi. org/10.1111/j.1574-6968.1990.tb03523.x

Roy P, Virus Res. 64, 69-123, 2005.

Roy P, Bishop DH, LeBlois H, Erasmus BJ, Vaccine 12, 805-811, 1994. https://doi.org/10.1016/0264-410X(94)90289-5

Roy P, Boyce M, Noad R, Natural Rev. Microbiol. 7, 120-128, 2009. https://doi.org/10.1038/nrmicro2052

Roy P, French T, Erasmus BJ, Vaccine 10, 28-32,1992. https://doi. org/10.1016/0264-410X(92)90415-G

Roy P, Fukusho A, Ritter DG, Lyons D, Nucleic Acids Res. 16, 11759-11767, 1988. https://doi.org/10.1093/ nar/16.24.11759

Roy P, Noad R, Hum. Vaccine 4, 5-12, 2008. https://doi.org/10.4161/ $\underline{\text { hv.4.1.5559 }}$ 
Roy P, Urakawa T, Van Dijk AA, Erasmus BJ, J. Virol. 64, 1998-2003, 1990.

Rybicki EP, Drug Discov. Today, 14, 16-24, 2009. https://doi. org/10.1016/j.drudis.2008.10.002

Rybicki EP, Virol. J. 11,205, 2014. https://doi.org/10.1186/s12985014-0205-0

Saegerman C, Berkvens D, Mellor PS, Emerg. Infect. Dis. 14, 539-544, 2008. https://doi.org/10.3201/eid1404.071441

Savini G, Hamers C, Conte A, Migliaccio P, Bonfini B, Teodori L, Di Ventura M, Hudelet P, Schumacher C, Caporale V, Vet. Microbiol. 133, 1-8, 2009. https://doi.org/10.1016/j. vetmic.2008.05.032

Savini G, Lorusso A, Paladini C, Migliaccio P, Di Gennaro A, Di Provvido A, Scacchia M, Monaco F, Transbound Emerg. Dis. 61, 69-74,2014. https://doi.org/10.1111/tbed.12004

Savini G, MacLachlan NJ, Sanchez-Vizcaino JM, Zientara S, Comp. Immunol. Microbiol. Infect. Dis. 31, 101-120, 2008. https://doi.org/10.1016/j.cimid.2007.07.006

Savini G, Ronchi GF, Leone A, Ciarelli A, Migliaccio P, Franchi P, Mercante MT, Pini A, Vet. Microbiol. 124,140-146, 2007. https://doi.org/10.1016/j.vetmic.2007.04.017

Schirtzinger EE, Jasperson DC, Ostlund EN, Johnson DJ, Wilson WC, J. Gen. Virol. 99(2), 157-168, 2018. https://doi. org/10.1099/jgv.0.000965

Singh KP, Maan S, Samuel AR, Rao S, Meyer AJ, Mertens PPC, Vet. Ital. 40, 479-483, 2005.

Spedicato M, Lorusso A, Salini R, Gennaro AD, Leone A, Teodori L, Casaccia C, Portanti O, Calistri P, Giovannini A, Savini G, Prev. Vet. Med. 136, 49-55, 2017. https://doi. org/10.1016/j.prevetmed.2016.11.016

Stevens DR, Stott J, Osburn BI, Giles R, Wiesehahn GP, Barber TL, Prog. Clin. Biol. Res. 178, 649-652, 1985.

Stewart M, Dovas CI, Chatzinasiou E, Athmaram TN, Papanastassopoulou M, Papadopoulos O, Roy P, Vaccine 30, 21312139, 2012. https://doi.org/10.1016/j.vaccine.2012.01.042

Stewart M, Dubois E, Sailleau C, Breard E, Viarouge C, Desprat A, Thiery R, Zientara S, Roy P, Vaccine 31, 553-558, 2013. https://doi.org/10.1016/j.vaccine.2012.11.016

Stewart M, Hardy A, Barry G, Pinto RM, Caporale M, Melzi E, Hughes J, Taggart A, Janowicz A, Varela M, Ratinier M, Palmarini M, J. Gen. Virol. 96, 3280-3293, 2015. https:// doi.org/10.1099/jgv.0.000267

Tacken MG, Daus FJ, Feenstra F, van Gennip RG, van Rijn PA (2015), Vaccine 33, 5539-5545. https://doi.org/10.1016/j. vaccine.2015.09.020

Thuenemann EC, Meyers AE, Verwey J, Rybicki EP, Lomonossoff GP, Plant Biotechnol. J. 11, 839-846, 2013. https://doi. org/10.1111/pbi.12076

Toussaint JF, Sailleau C, Breard E, Zientara S, De Clercq K, J. Virol. Methods 140, 115-123, 2007. https://doi.org/10.1016/j. jviromet.2006.11.007
Tulman ER, Afonso CL, Lu Z, Zsak L, Kutish GF, Rock DL, J. Virol. 78, 353-66, 2004. https://doi.org/10.1128/JVI.78.1.353$\underline{366.2004}$

Tweedle N, Mellor PS, Version 1.5. Report to the Department of Health, Social Services and Public Safety U.K. (DEFRA), 25 p. http://archive.defra.gov.uk/foodfarm/farmanimal/ diseases/atoz/documents/bluetongue_technical.PDF, 2002.

Umeshappa CS, Singh KP, Pandey AB, Singh RP, Nanjundappa RH, Vaccine 28, 2522-2531, 2010. https://doi.org/10.1016/j. vaccine.2010.01.039

van Gennip RG, van de Water SG, Maris-Veldhuis M, van Rijn PA, PLoS ONE 7, e44619, 2012. https://doi.org/10.1371/ journal.pone.0044619

van Rijn PA, Daus FJ, Maris-Veldhuis MA, Feenstra F, van Gennip RGP, Vaccine 35, 231-237, 2017. https://doi. org/10.1016/j.vaccine.2016.11.081

van Rijn PA, van de Water SG, van Gennip HG, Vaccine 31, 5005 5008, 2013. https://doi.org/10.1016/j.vaccine.2013.08.089

van Zyl AR, Meyers AE, Rybicki EP, Biotech. Reports. 9, 15-24, 2016. https://doi.org/10.1016/j.btre.2015.12.001

Veronesi E, Hamblin C, Mellor PS, Vaccine 23, 5509-5516, 2005. https://doi.org/10.1016/j.vaccine.2005.07.039

Verwoerd DW, Virology 38, 203-212, 1969. https://doi org/10.1016/0042-6822(69)90361-4

Verwoerd DW, Erasmus BJ, In Coetzer JA, Tustin RC (Eds.), Infectious Diseases of Livestock, 2nd ed. Oxford University Press, Cape Town, pp. 1201-1220, 2004.

Vishwaradhya TM, Minakshi P, Ranjan K, Supriya, Kumar P, Prasad G, Vet. World. 6, 554-557; 2013. https://doi.org/10.5455/ vetworld.2013.554-557

Wade-Evans AM, Romero CH, Mellor P, Takamatsu H, Anderson J, Thevasagayam J, Fleming MJ, Mertens PP, Black DN, Virology 220, 227-231, 1996. https://doi.org/10.1006/ viro.1996.0306

WHO: http://www.who.int/vaccine_safety/initiative/tech_support/ Part-2.pdf, 2013.

Zhang N, Li Z, Zhang F, Zhu J, Vet. Ital. 40, 51-56, 2004.

Zhang Y, Du X, Li W, Li J, Liu J, Zhu J, Zhang N, Arch. Virol. 155, 281-286, 2010. https://doi.org/10.1007/s00705-009$\underline{0574-7}$

Zhugunissov K, Yershebulov Z, Barakbayev K, Bulatov Y, Taranov D, Amanova Z, Abduraimov Y, Vet. Res. Commun. 39, 203-210, 2015. https://doi.org/10.1007/s11259-0159643-4

Zientara S, MacLachlan NJ, Calistri P, Sanchez-Vizcaino J-M, Savini G, Expert Reviews Vaccines 9, 989-991, 2010. https://doi. org/10.1586/erv.10.97 